\title{
Dating Exposed Rock Surfaces in the Arctic by Lichenometry: The Problem of Thallus Circularity and Its Effect on Measurement Errors
}

\author{
JOHN L. INNES ${ }^{1}$
}

(Received 14 May 1985; accepted in revised form 27 February 1986)

\begin{abstract}
Lichenometry represents an extremely useful dating technique in the Arctic. It is most appropriate for exposed rock surfaces, which are abundant in most arctic environments, and on occasion it represents the only suitable technique for estimating the age of a surface. As a result, lichenometry is being used in an increasing number of arctic studies. Despite this, controversy still surrounds the manner in which individual thalli are measured. The majority of workers measure either the longest axis or the diameter of the largest inscribed circle. The measurement error involved in the latter is significantly greater than that for longest axis measurements. The proportion of circular thalli on a surface decreases through time, and studies that use circular thalli only or inscribed circle diameters will underestimate the maximum growth rate of lichens on older surfaces.
\end{abstract}

Key words: dating, lichenometry, moraines, measurement errors

RÉSUMÉ. La lichenométrie est une technique de datation des plus efficaces dans l'Arctique. Les surfaces rocheuses exposées, abondantes dans la plupart des milieux arctiques, se prêtent le mieux à cette technique. Celle-ci représente aussi à l'occasion la seule façon convenable de datation d'une surface. La lichenométrie est donc de plus en plus utilisée dans les études arctiques. Il reste tout de même une certaine controverse quant à la méthode de mesure des thalles individuels. La plupart des chercheurs mesurent l'axe le plus long ou encore le diamètre du plus grand cercle inscrit. Le taux d'erreur de mesure dans cette dernière méthode est beacoup plus élevé que celui de la mesure de l'axe le plus long. La proportion de thalles circulaires sur une surface diminue avec le temps et les études qui ne tiennent compte que des thalles circulaires ou des diamètres de cercles inscrits vont sous-estimer le taux de croissance maximal des lichens sur des surface plus âgées.

Mots clés: datation, lichenométrie, moraines, erreurs de mesure

Traduit pour le journal par Maurice Guibord.

\section{INTRODUCTION}

Lichenometry has been increasingly used as a dating technique in arctic environments. Examples of the application of the method include studies in the central Brooks Range of Alaska (Ellis et al., 1981; Calkin and Ellis, 1984; Ellis and Calkin, 1984), Baffin Island (Carrara and Andrews, 1972; Locke and Locke, 1977; Andrews and Barnett, 1979), Axel Heiberg Island (Beschel, 1961), Greenland (Beschel and Weidick, 1973; Pitman, 1973; Gordon, 1981), Spitsbergen (André, 1985) and, in the Antarctic, studies in the South Shetland Islands (Ten Brink and Curl, 1973; Birkenmajer, 1980a, b). The majority of studies deal with glacial moraine sequences, but the above studies indicate that lichenometry can also be successfully applied to the dating of other geomorphological phenomena and to many archaeological structures. There have been several recent investigations into the methodology of the technique, with the result that it is becoming increasingly reliable.

Within this context, it is surprising that controversy still surrounds its most fundamental aspect: the measurement of individual lichen thalli. Some workers measure the longest axis of a thallus, whereas others measure the shortest axis or, as it has been termed (Locke et al., 1979), the diameter of the largest inscribed circle (Fig. 1). Additional variations have occurred, with some workers measuring only circular thalli and others measuring all thalli, regardless of shape. This author (Innes, 1985) has reviewed the problem, suggesting that the use of the longest axis is logically and statistically the optimum strategy, but this conclusion was limited by a lack of data.

The arguments for using circular thalli or the largest inscribed circle diameters are based on a desire to omit coalesced thalli from measurements in lichenometry. This problem is particularly apparent on very old substrates, where, for example, the
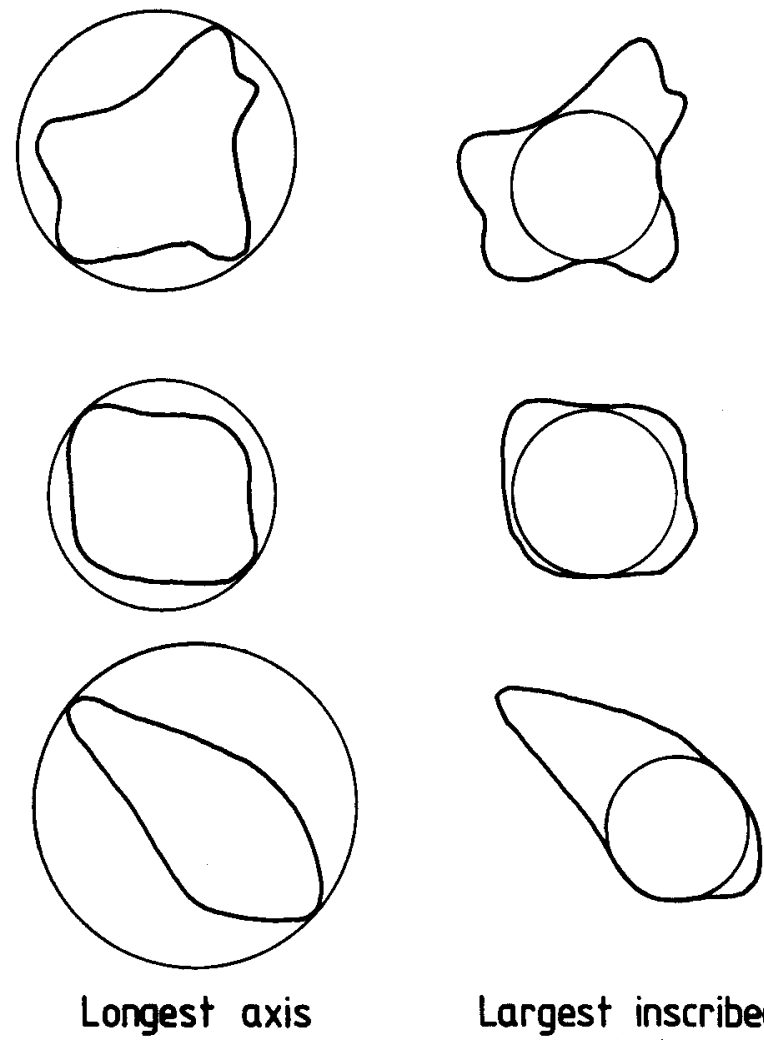

Largest inscribed circle

FIG. 1. Methods for measuring a lichen thallus: longest axis and largest inscribed circle.

\footnotetext{
${ }^{1}$ Forestry Commission, Forest Research Station, Alice Holt Lodge, Wrecclesham, Farnham, Surrey GU10 4LH (formerly, Geography Section, 
cover of Rhizocarpon species is very high and many thalli adjoin. However, the use of the largest inscribed circle of circular or near-circular thalli has two major drawbacks. Firstly, it involves a partly subjective measurement, in that the diameter of an imaginary circle fitted within the thallus boundaries has to be determined. Secondly, through time, there is an increasing probability that a thallus will become irregular in shape. Karlén, cited in Locke et al. (1979), and Innes (1985) have argued that in the case of a thallus growing at the maximum rate for a site any divergence in circularity will be due to a reduction in the rate of growth of particular radii as opposed to an increase in the rate of growth along an axis. Consequently, the use of the largest inscribed circle diameter will result in an underestimate of the maximum growth rate for that site. These assertions refer specifically to the Rhizocarpon group. Hill (1984) has shown that in the case of placodioid lichens (e.g., Xanthoria elegans, Diploicia canescens), there may be an increase in circularity through time. However, his results were obtained for very small thalli (radii $<10 \mathrm{~mm}$ ) and it is unknown whether they extend to larger thalli.

\section{REPRODUCIBILITY OF DIFFERENT AXIS MEASUREMENTS}

A major criticism of the largest inscribed circle method is that the determination of the diameter is partly subjective. The only way in which this could be overcome would be the use of a transparent circular measure placed over the thallus. Even with this, accurate measurements to the nearest millimetre would be difficult. The subjective element in the measurement brings into

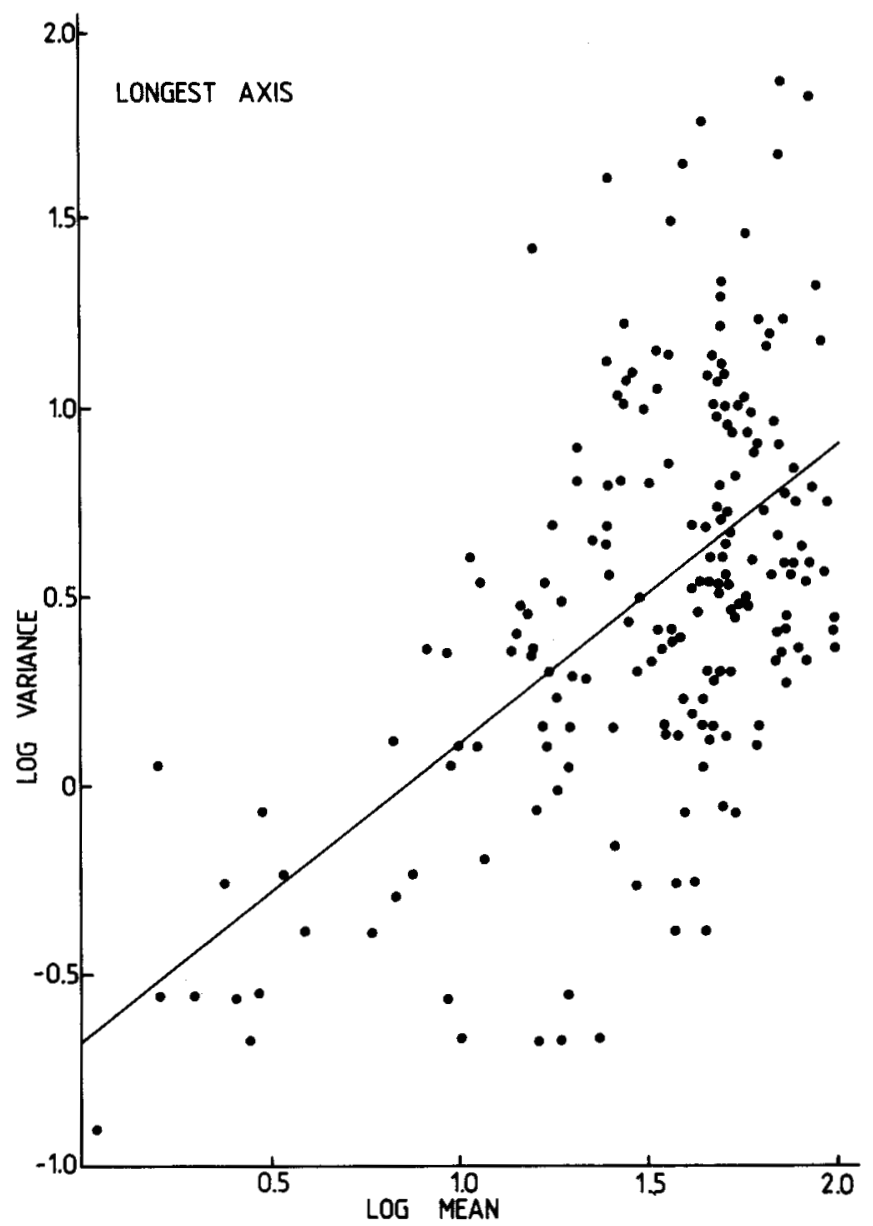

question its reproducibility. This can be examined experimentally. Eight observers were requested to measure the longest axis and the largest inscribed circle diameters of 200 marked thalli. Measurements were made using transparent plastic rulers, and values were recorded to the nearest $1 \mathrm{~mm}$. The sizes of the thalli (long axis) were fairly evenly distributed between 1 and $110 \mathrm{~mm}$. In addition, measurements by a single observer of the longest axis of each thallus, using dial callipers and to 0.01 $\mathrm{mm}$ accuracy, have been included in the analysis.

There is a considerable amount of variation in the results obtained by different observers. The results of the two measurement techniques by the eight observers can be summarized by the mean and variance, and plots of log variance against log mean are given in Figure 2. In both cases, there are significant positive correlations between the two (for the longest axis, $\mathrm{r}=$ 0.5587 ; for the largest inscribed circle, $r=0.6987 ; \mathrm{p}<0.001$ ). The correlations indicate that the degree of variation between observers increases with increasing thallus size. The rate of increase is greater with the largest inscribed circles. It should be stressed that the variances represent the measurement errors only. Further errors arise when searches are involved due to variations in the search efficiency of individual operators.

Some of the errors described above can be specifically attributed to the group of observers involved in this study. Thallus measurements were not randomly distributed: some observers obtained consistently low results whereas others obtained above-average results. This can be examined by analysis of variance techniques if the following basic model is

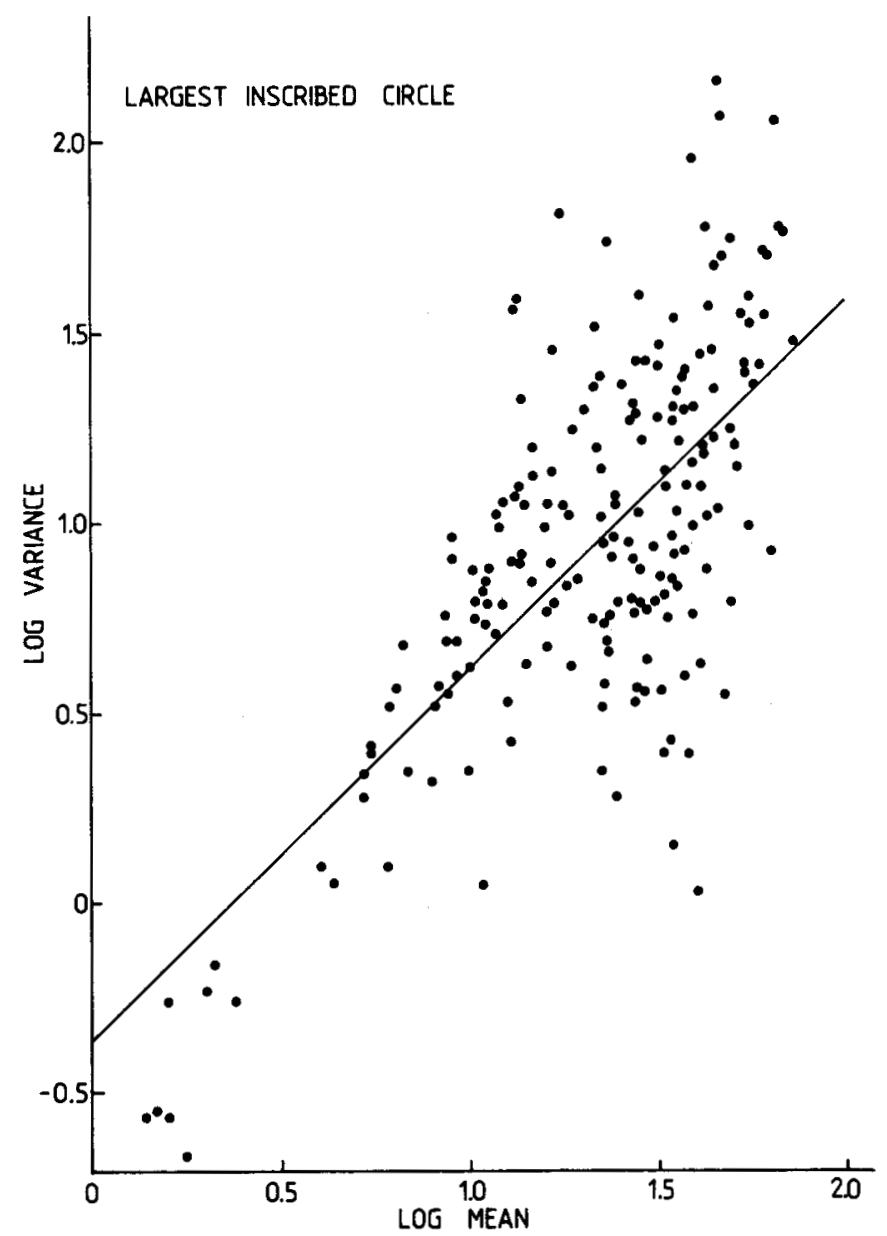

FIG. 2. Plots of log variance against log mean for longest axis (2a) and largest inscribed circle measurements (2b). 
adopted (Freeman, 1973; Mather and Jinks, 1977; Topham, pers. comm. 1985):

$$
X_{i j k}=u+T_{i}+O_{j}+b\left(O_{j} T_{i}\right)+e_{i j k}
$$

where $\mathrm{i}$ - thallus, $\mathrm{j}$ - observer, $\mathrm{k}$ - measurement method

$u-$ mean of the observations

$\mathrm{T}_{\mathrm{i}}$ - thallus size measured from mean

$\mathrm{O}_{\mathrm{j}}$ - observer (constant) bias

$b\left(\mathrm{O}_{j} \mathrm{~T}_{\mathrm{i}}\right)$ - systematic (multiplicative) bias

$\mathrm{e}_{\mathrm{ijk}}$ - an error term

The two sources of bias and the error term are of particular interest to this study. The data presented in Figure 2 suggest that $\mathrm{e}_{\mathrm{ijk}}$ increases with increasing thallus size, indicating that the absolute measurement error is greater for larger than for smaller thalli.

The existence of systematic bias in the measurements can be tested using Tukey's test for additivity (Tukey, 1949). Tukey attributed non-additivity to two causes. Firstly, one or more observations may be unusually discrepant, and secondly, the analysis may have been made in terms where the effects of rows and columns are not additive. The first of these can be tested by plotting the sums of cross products against the row means. Any anomalous values will appear as outliers (Fig. 3). Several groups of measurements have been omitted at this stage.

With both measurement techniques, the assumption of additivity is untenable $(\mathrm{F}=10.6174$ [longest axis]; $\mathrm{F}$ $=27.7066$ [largest inscribed circle]; $p<0.01$ ). Consequently, the data have to be transformed, using Tukey's value $\hat{\mathrm{p}}$. In the case of the longest axes this is calculated at 0.6258 , and for the largest inscribed circle it is $\mathbf{0 . 6 1 6 2}$. The data now satisfy the assumption and can be analyzed by two-way analyses of variance. The results are presented in Table 1 . They indicate that the differences between observers are significant $(p<0.01)$. Of particular interest is the higher $F$ value obtained for the inscribed circle measurements, suggesting that the degree of variation is greater for this measure than it is for the longest axes. The difference is significant $(F=5.983, p<0.01)$.

Analysis of the squared residuals of these two data sets indicates that they do not differ significantly between operators (Bartlett's test of homogeneity of variance; $\mathrm{X}^{2}$ for longest axes - 3.9939; forlargest inscribed circles $-0.029 ; p>0.05$ ). The variances can also be compared "within" observers to assess the extent to which individual observers vary in their measurements. In six cases out of eight the largest inscribed circle measurements were more variable than the longest axis measurements. Of the remaining two, one difference was insig-

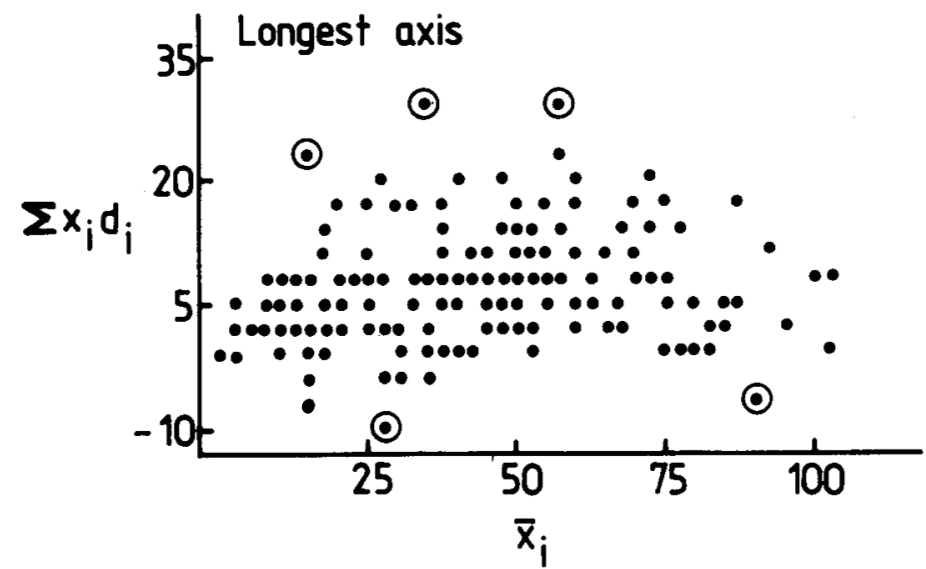

TABLE 1. Analysis of variance of longest axis and largest inscribed circle data

\begin{tabular}{lrrrr}
\hline \hline & $\begin{array}{c}\text { Degrees of } \\
\text { freedom }\end{array}$ & $\begin{array}{r}\text { Sum of } \\
\text { squares }\end{array}$ & $\begin{array}{r}\text { Mean } \\
\text { square }\end{array}$ & \multicolumn{1}{c}{ F } \\
\hline Longest axis & & & & \\
$\quad$ Operators & 8 & 33.5 & 4.19 & 29.93 \\
Thalli & 190 & 27765.1 & 146.13 & 1043.78 \\
Error & 1520 & 210.0 & 0.14 & \\
Total & 1718 & 28008.6 & & \\
& & & & \\
Largest inscribed circle & 7 & 175.5 & 25.07 & 89.54 \\
$\quad$ Operators & 186 & 12979.2 & 69.78 & 249.21 \\
$\quad$ Thalli & 1302 & 368.8 & 0.28 & \\
Error & 1495 & 13523.5 & & \\
$\quad$ Total & & & & \\
\hline \hline
\end{tabular}

nificant and the remaining one had a significant result in the reverse direction. This last observer had an average amount of variation in the largest inscribed circle measurements but an above-average amount of variation in the longest axis measurements, suggesting errors in the longest axis measurements.

The remaining observation that should be made about these data refer to the calliper measurements. These showed the least amount of variation among the squared residuals. In five cases out of eight, the variance was significantly $(\mathrm{p}<0.01)$ smaller than that for the ruler measurements. In terms of measured values, the calliper measurements tended to be slightly larger than the ruler measurements (Fig. 4). This can probably be attributed to the greater accuracy involved in the measurement of the prothallus when using callipers.

\section{ERRORS ATTRIBUTABLE TO TIME-DEPENDENT CHANGES IN LICHEN SHAPE}

The use of the largest inscribed circle can also be criticized on theoretical grounds. Innes (1985) has argued that as a thallus gets larger, the probability of growth inhibition along any given axis will increase. Consequently, a decrease in circularity will occur among larger lichens. The measurement of the largest inscribed circle will result in such growth inhibitions being included in any determination of the growth rate. As lichenometry is based on the maximum growth rate of the single or several largest thalli on a deposit, measurements that show evidence of growth inhibition (i.e., the shortest axis of elliptical or irregular thalli) should not be included. A decrease in the circularity of lichens through time also has implications for

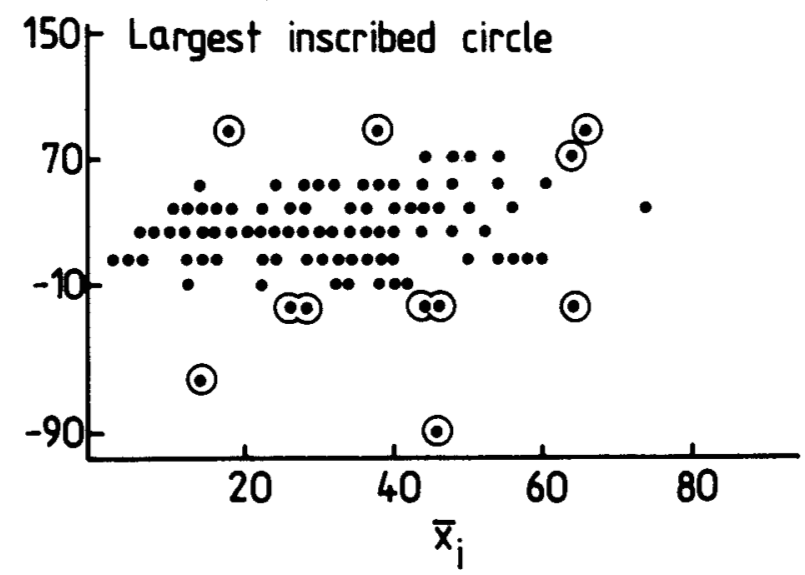

FIG. 3. Sums of cross products $\left(\Sigma \mathbf{x}_{\mathrm{i}} \mathrm{d}_{\mathrm{i}}\right)$ plotted against row means $(\overline{\mathrm{x}})$ for longest axis and largest inscribed circle measurements. Anomalous values äre circled. 


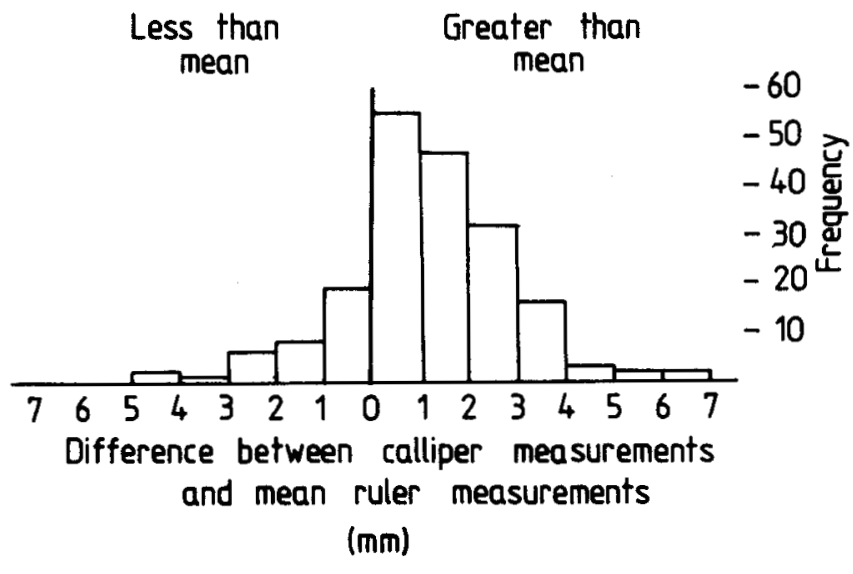

FIG. 4. Difference between calliper measurements and the mean ruler measurements for each thallus.

studies that use circular thalli only. If circularity decreases as a thallus increases in size, then the population of circular thalli will drop through time. This means that the probability of determining the maximum growth rate at that site will also fall in proportion to the size of the thalli measured.

There is only a limited amount of evidence in the literature that suggests that circularity decreases through time. The standard method by which this has been portrayed is by the use of scattergrams relating the largest and shortest axes (Matthews, 1974; Griffey, 1977; Innes, 1985). These have usually been constructed from data from a surface of uniform age or from data drawn from a wide variety of surfaces. This has led to difficulties of interpretation, as two trends may be apparent. Firstly, on a single surface larger thalli may be less circular than smaller ones due to the greater probability of having encountered a factor resulting in growth inhibition. Secondly, on older surfaces the total lichen cover is higher, and thalli might therefore be expected to be less circular than thalli of similar diameters on younger surfaces.

Both of these trends were examined using data from the moraine system at Nigardsbreen in southwest Norway. This glacier foreland was chosen as it is thought to have the bestcontrolled dates for the moraines in south Norway (Andersen and Sollid, 1971; Innes, 1986; Matthews et al., 1986). There is a certain amount of controversy surrounding some of the lichenometric dates, and for the purposes of this study, the moraines have been numbered in order of increasing age. The known dates and the dates proposed by Andersen and Sollid (1971) and Innes (1986) are given in Table 2.

The data presented below were collected by several observers. This forms a potential source of bias. To evaluate the extent of this, the same techniques as described above were used on a modified data set. This data set consisted of the ratios of the largest inscribed circle measurements to the longest axis measurements, such that a circular thallus would produce a ratio of 1.00 and elongate thalli would approach zero. An analysis of variance of these data indicated that the additivity assumption was satisfied and that there were no significant $(p=0.01)$ differences between operators. Consequently, the ratio data obtained by different observers can be analyzed together.

On each moraine at Nigardsbreen, samples of 120 thalli in every size class present were measured. The first 120 thalli encountered with the longest axes in classes of $1.9 \mathrm{~mm}, 10-19$ $\mathrm{mm}, 20-29 \mathrm{~mm}$, etc., were recorded, with both the long and short axes being noted. These data are shown in Figure 5, where standard scattergrams have been presented. Sample sizes were reduced where only a few thalli in the relevant size class were present on the moraine, and on older moraines samples of the smallest thalli were restricted since lichenometry is essentially concerned with the largest thalli on a surface.

To investigate whether there is any evidence of either of the trends in decreasing circularity described above, the data shown in Figure 5 were converted to percentages (largest inscribed circle $\times 100 /$ longest axis). These have been classified by moraine and by size (10 $\mathrm{mm}$ [longest axis] classes). The means and variances of each subset are given in Table 3 . The means have been investigated by an analysis of variance (Table 4 ). There is no significant $(\mathrm{p}=0.05$ ) difference between the size classes, but the data from each moraine are significantly different. In the case of the variances, significant differences exist in both directions (Table 5). The overall trends are for a decrease in circularity on older moraines and a decrease in the variances among larger thalli on individual moraines and among thalli on older moraines.

These trends can be investigated in more detail in several ways, two of which are examined here. In Figure 6, the means within each class interval have been plotted against the moraine. Although there is an overall decrease in circularity through time, the scattergram suggests that the situation is more complex. The means decrease between moraines 1 and 6 , but then appear to increase. The increase is not confirmed statistically. The values for moraine 8 are not significantly different $(0.05>p>0.01)$ from those on moraine 6 .

An alternative method for examining the observed trends is by the analysis of particular groups of thallus ratios. The most critical of these is the $91-100 \%$ class, since it represents the near-circular thalli. In Figure 7, the percentages of thalli in this class at different thallus diameters and on different moraines are shown. Although some scatter exists among the data, the overall trend for a decrease in the frequency of thalli in the class through time is apparent. This is confirmed statistically by regression analysis: the slope is negative $(r=0.7065, p<0.01)$. This confirms the hypothesis that the proportion of circular and nearcircular thalli decreases with increasing thallus size. This was not apparent from the analysis of variance, although the trend was probably masked by an absence of any significant change in the proportion of oval thalli (ratios of 50-80\%).

TABLE 2: Known and estimated dates of moraines at Nigardsbreen, southwest Norway, examined in this study

\begin{tabular}{cccr}
\hline $\begin{array}{c}\text { Moraine } \\
\text { number }\end{array}$ & Known date $^{1}$ & & \\
\hline 1 & $1930 \mathrm{AD}$ & & \\
2 & $1875 \mathrm{AD}$ & $1860 \mathrm{AD}^{3}$ & $1843 \mathrm{AD}^{4}$ \\
3 & & $1850 \mathrm{AD}^{3}$ & $1835 \mathrm{AD}^{4}$ \\
4 & & $1840 \mathrm{AD}^{3}$ & $1820 \mathrm{AD}^{4}$ \\
5 & & $1790 \mathrm{AD}^{3}$ & $? 1795 \mathrm{AD}^{4}$ \\
6 & & $?(1750-1790 \mathrm{AD})^{3}$ & $1789 \mathrm{AD}^{4}$ \\
7 & & & \\
8 & $1748 \mathrm{AD}$ & & \\
\hline \hline
\end{tabular}

\footnotetext{
${ }^{1}$ From historical records.

2 By lichenometry.

${ }^{3}$ Andersen and Sollid, 1971.

4 Innes, 1986.
} 


\begin{tabular}{|c|c|c|c|c|c|c|c|c|c|}
\hline & $\begin{array}{l}\left(S^{\prime}\llcorner D I)\right. \\
\left(S^{\prime} 8 S\right)\end{array}$ & $\begin{array}{l}9.941 \\
\text { S19 }\end{array}$ & $\begin{array}{l}9.822 \\
9.09\end{array}$ & $\begin{array}{l}9.56 \mathrm{I} \\
\varepsilon: 19\end{array}$ & $\begin{array}{l}6 . \varsigma I Z \\
\text { S.6S }\end{array}$ & $\begin{array}{l}(6 \cdot I 0 Z) \\
(0 \angle 9)\end{array}$ & $\begin{array}{l}\left(0^{\circ} \text { SSI }\right) \\
\left(8^{\circ} 8 S\right)\end{array}$ & 8 & $\begin{array}{l}\bar{\rho} \\
\underline{x}\end{array}$ \\
\hline \multirow{3}{*}{$\begin{array}{l}\left(I^{\prime} 0 z z\right) \\
\left(8^{\prime} 9 S\right)\end{array}$} & $6 . \varepsilon 9 \mathrm{I}$ & $\nabla .6 L I$ & $6^{\circ} \angle S Z$ & $8^{\circ} \angle E Z$ & $(0.8 \varepsilon Z)$ & $(0.69 \tau)$ & $\left(I^{\circ}\llcorner I E)\right.$ & & 8 \\
\hline & $\varepsilon \angle S$ & $8 \angle 5$ & $S^{\prime} 6 S$ & $2 \cdot 09$ & $(t \div s 9)$ & $(6 \mathrm{SS})$ & $(9.6 \mathrm{~S})$ & $L$ & $\underline{\mathbf{x}}$ \\
\hline & $\begin{array}{l}\left(I^{\circ} 60 Z\right) \\
\left(z^{\prime}\llcorner S)\right.\end{array}$ & $\begin{array}{l}6.58 I \\
6.95\end{array}$ & $\begin{array}{l}5.80 z \\
1.85\end{array}$ & $\begin{array}{l}9 \circ z Z \\
0 \circ \mathcal{\circ}\end{array}$ & $\begin{array}{l}L^{\prime} 0 I Z \\
Z^{\prime} L S\end{array}$ & $\begin{array}{l}(9.0 \varepsilon \mathrm{I}) \\
\left(6^{\circ} 0 \mathrm{~S}^{\prime}\right)\end{array}$ & $\begin{array}{l}\left(t^{\prime} 66 \mathrm{I}\right) \\
\left(\mathrm{C}^{\prime}<\mathcal{S}\right)\end{array}$ & 9 & $\begin{array}{l}\rho \\
\underline{\mathbf{x}}\end{array}$ \\
\hline \multirow[t]{5}{*}{$\begin{array}{l}(\text { I } 0 z Z) \\
\left(8^{\circ} 9 \varsigma\right)\end{array}$} & $\begin{array}{l}t^{\circ} 6 t z \\
6 * t s\end{array}$ & $\begin{array}{l}L \cdot \varepsilon 8 I \\
\forall \forall \subseteq\end{array}$ & $\begin{array}{l}6.8 \angle I \\
6.5 S\end{array}$ & $\begin{array}{l}\varepsilon L L Z \\
L \mapsto S\end{array}$ & $\begin{array}{l}6.96 E \\
L .8 S\end{array}$ & $\begin{array}{l}0 . S L E \\
T^{\prime} S S\end{array}$ & $\begin{array}{l}0 . t s t \\
8.9 s\end{array}$ & $s$ & $\begin{array}{l}\rho \\
\underline{\mathbf{x}}\end{array}$ \\
\hline & & $\begin{array}{l}(\downarrow \cdot S I Z) \\
(L \cdot \varepsilon 9)\end{array}$ & $\begin{array}{l}8^{\prime} 66 \mathrm{I} \\
0^{\prime} 09\end{array}$ & $\begin{array}{l}90 \$ 2 \\
t \rightarrow 5\end{array}$ & $\begin{array}{l}\text { I'SEE } \\
S^{\prime} E S\end{array}$ & $\begin{array}{l}0.8 I \mathcal{E} \\
\text { T.ES }\end{array}$ & $\begin{array}{l}\angle .8 \angle E \\
6.6 S\end{array}$ & $t$ & $\begin{array}{l}\mathrm{g} \\
\underline{\mathbf{x}}\end{array}$ \\
\hline & & & & $\begin{array}{l}6.812 \\
t .65\end{array}$ & $\begin{array}{l}8 \cdot t L I \\
t^{\prime} \varsigma 9\end{array}$ & $\begin{array}{l}6 . S S Z \\
2.89\end{array}$ & $\begin{array}{l}9 \cdot \text { ISE } \\
t \neq 9\end{array}$ & $\varepsilon$ & $\begin{array}{l}\rho \\
\underline{x}\end{array}$ \\
\hline & & $\begin{array}{l}\left(\varepsilon^{*} 0 \varepsilon I\right) \\
\left(0^{\circ} 09\right)\end{array}$ & $\begin{array}{l}\text { Z'ZII } \\
8^{\prime} E 9\end{array}$ & $\begin{array}{l}\angle 612 \\
L \cdot I L\end{array}$ & $\begin{array}{l}\tau \cdot 6 S I \\
0.29\end{array}$ & $\begin{array}{l}\varsigma .60 \varepsilon \\
9.69\end{array}$ & $\begin{array}{l}\tau^{\prime} \varepsilon S \tau \\
\varepsilon^{\prime} I L\end{array}$ & $\tau$ & $\begin{array}{l}g \\
\underline{\mathbf{x}}\end{array}$ \\
\hline & & & & & $\begin{array}{l}8^{\circ} 021 \\
t^{\prime} 99 \\
\end{array}$ & $\begin{array}{l}5.60 z \\
8.29 \\
\end{array}$ & $\begin{array}{l}9 . \angle S E \\
6 . \varepsilon 9 \\
\end{array}$ & I & $\begin{array}{l}\mathrm{g} \\
\underline{\mathrm{x}}\end{array}$ \\
\hline $6 L-0 L$ & $69-09$ & $6 S-0 S$ & $6 t=0 t$ & $6 \varepsilon-0 \varepsilon$ & $62-02$ & $6 \mathrm{I}-0 \mathrm{I}$ & 6-I & วu!exoW & \\
\hline
\end{tabular}

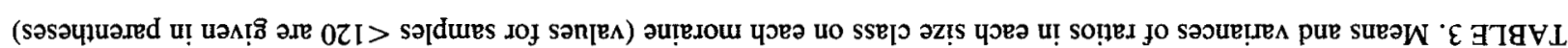

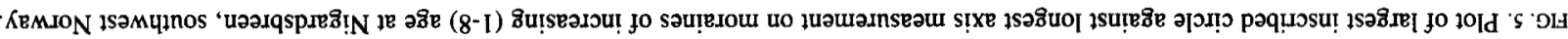

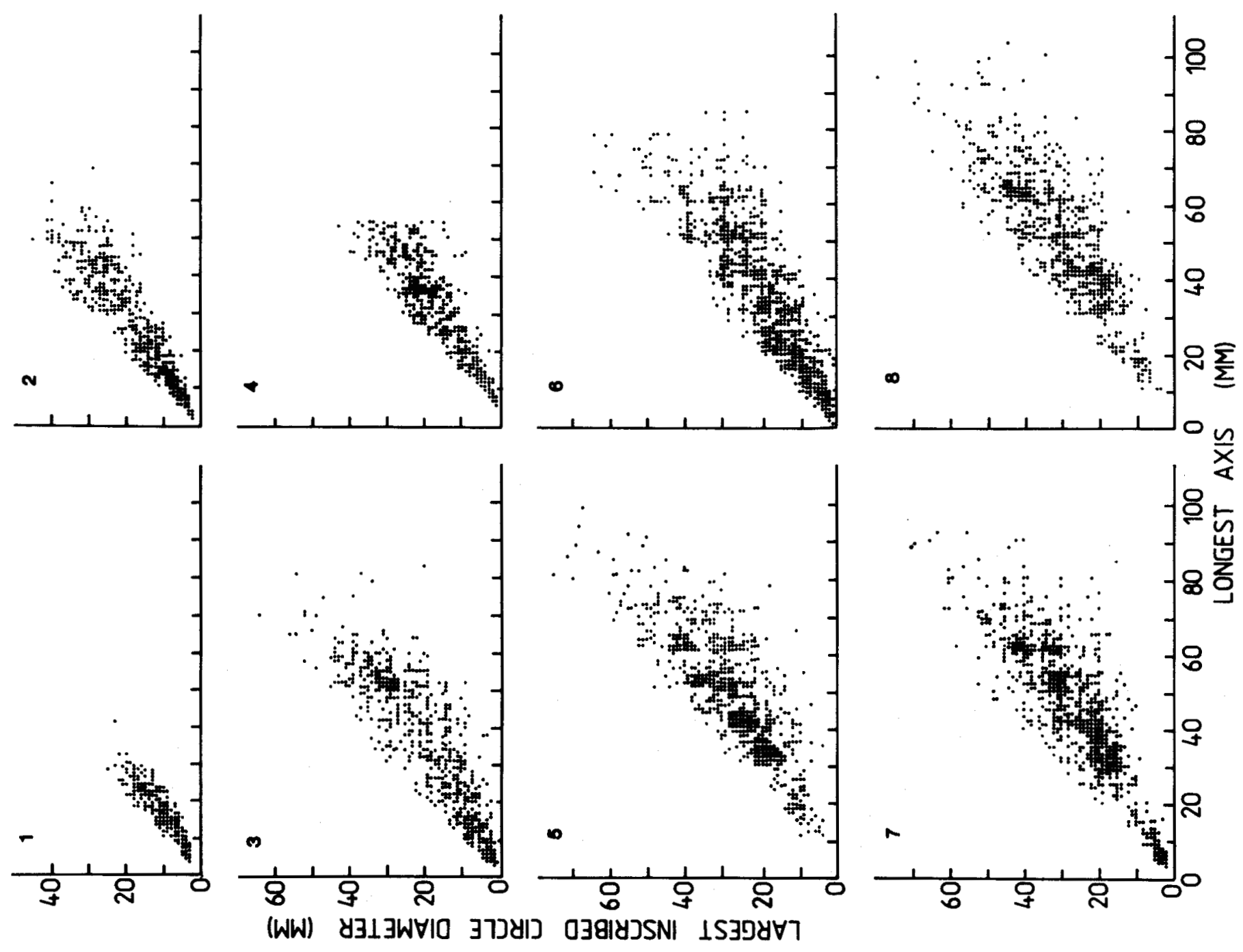


TABLE 4. Analysis of variance of mean ratios

\begin{tabular}{lcccc}
\hline \hline & $\begin{array}{c}\text { Degrees of } \\
\text { freedom }\end{array}$ & Sums of squares & Means square & F \\
\hline Age & 7 & 690.2 & 98.6 & 12.739 \\
Size & 7 & 98.2 & 14.0 & 1.8088 \\
Error & 43 & 322.9 & 7.7 & \\
Total & 57 & 1121.3 & & \\
\hline \hline
\end{tabular}

TABLE 5. Analysis of variance of ratio variances

\begin{tabular}{lcccc}
\hline \hline & $\begin{array}{c}\text { Degrees of } \\
\text { freedom }\end{array}$ & Sums of squares & Mean square & F \\
\hline Age & 7 & 87671.6 & 12524.5 & 4.5141 \\
Size & 7 & 81202.7 & 13533.8 & 4.8779 \\
Error & 43 & 119305.4 & 2774.5 & \\
Total & 57 & 288179.6 & & \\
\hline \hline
\end{tabular}

\section{CONCLUSIONS}

The results presented in this paper suggest that the use of largest inscribed circle measurements in lichenometry should be rejected for two completely independent reasons. Firstly, measurements of the largest inscribed circle diameter show a significantly greater degree of variation than do measurements of longest axes, with the implication that the results are less reproducible. Secondly, it has been shown that with increasing thallus size, the proportion of circular or near-circular thalli decreases. Thus, on a young moraine there will be a higher proportion of circular thalli than on an older moraine. The effect of this will be to reduce on older deposits the probability of measuring a thallus that has grown at the maximum rate for that

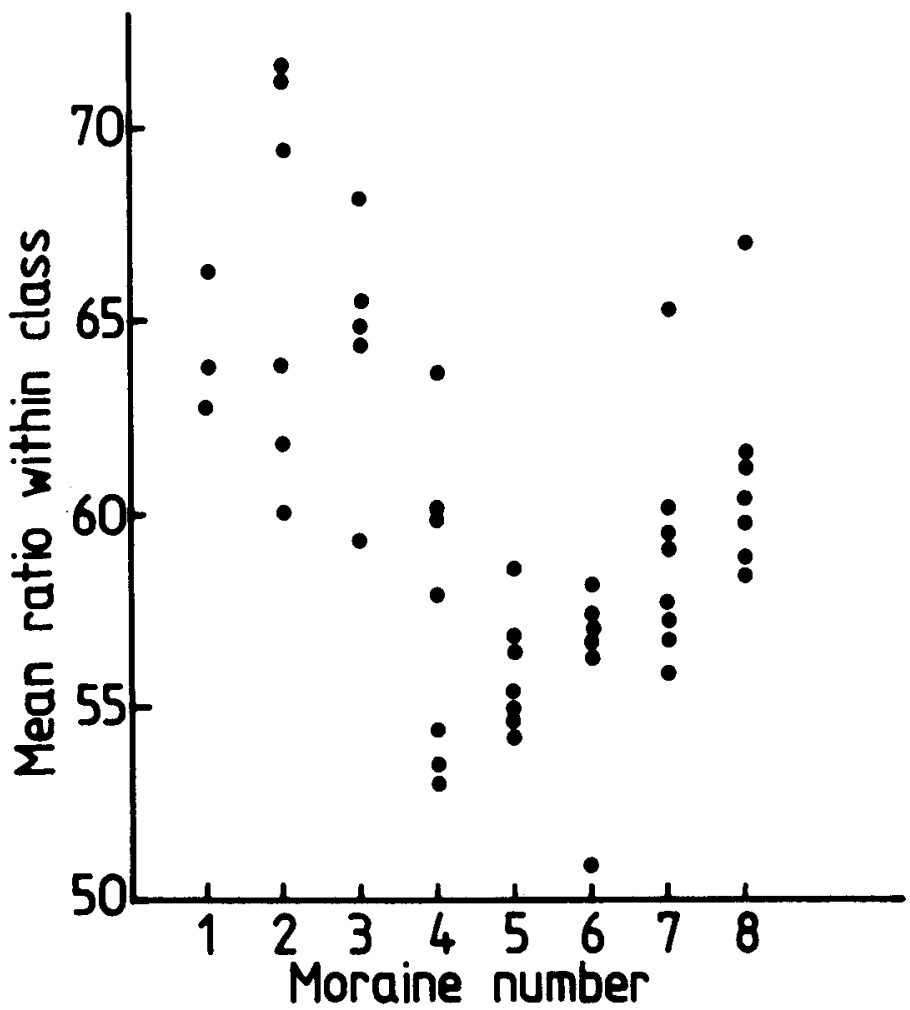

FIG. 6. Mean ratio within each $10 \mathrm{~mm}$ class interval plotted against moraine. Moraines increase in age from left to right. site. This will result in any derived growth curve being depressed at larger diameters.

The problem of measuring coalesced thalli remains. In the majority of cases, it is possible to recognize such thalli by changes in the colour of the areolae or by a strip of prothallus running through the areolae. Where neither of these exist, it may be possible to recognize anomalously large "thalli" statistically (Innes, 1984, 1985). In addition, if an averaging procedure is used (Matthews, 1974), the effects of any coalesced thallus on the overall data will be substantially reduced, provided that only one or two such thalli have been included. As stated above, it is usually possible to recognize the majority of coalesced thalli, and it is therefore likely that the number incorporated into lichenometric measurements will be negligible. They may, however, occur, and this possibility must be taken into account when estimating the reliability of lichenometric data.

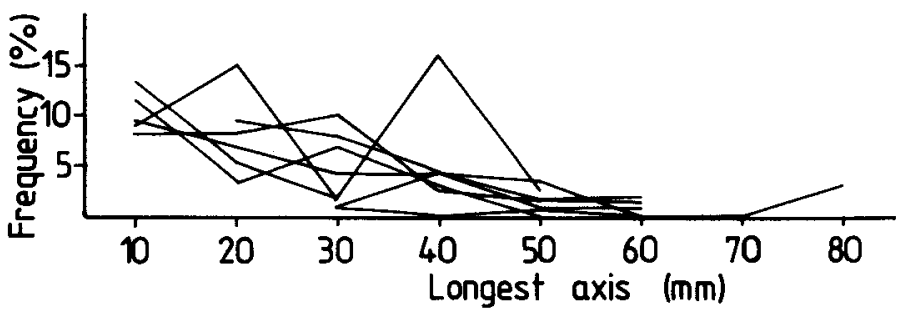

FIG. 7. Decline in frequency of circular thalli on moraines of increasing age. Each line connects data from the same moraine surface.

\section{ACKNOWLEDGEMENTS}

This work was undertaken while the author was in receipt of a U.K. Natural Environment Research Council Fellowship. It represents part of the work undertaken by the Cambridge Norwegian Expedition 1984, which received financial support from Mobil Exploration Norway Inc., Marathon International Petroleum (G.B.) Ltd., Gilchrist Educational Trust, the Royal Geographical Society, Cambridge Expeditions Fund, the British Ecological Society and the Ryvita Co. Ltd. The following are gratefully acknowledged for their assistance in the field: Jonathan Hodge, Peter Hopkins, Stuart Jackson, Nicholas Jeffreys, Clive Moody, Lucinda Nias and Jennifer Sandall. I am extremely grateful to Dr. Pauline Topham for suggesting the basic statistical model used in the study and for some detailed comments on an earlier version of this manuscript.

\section{REFERENCES}

ANDERSEN, J.L., and SOLLID, J.L. 1971. Glacial chronology and glacial geomorphology in the marginal zones of the glaciers, Midtdalsbreen and Nigardsbreen, south Norway. Norsk geografisk Tidsskrift 25:1-38.

ANDRÉ, M.-F. 1985 Lichénometrie et vitesses d'évolution des versants arctiques pendant l'Holocene (région de la Baie du Roi, Spitsberg, 79 N). Revue de Géomorphologie Dynamique 1985(2):49-72.

ANDREWS, J.T., and BARNETT, D.M. 1979. Holocene (Neoglacial) moraine and proglacial lake chronology, Barnes Ice Cap. N.W.T., Canada. Boreas 8:341-358.

BESCHEL, R.E. 1961. Botany: and some remarks on the history of vegetation and glacierization. In: Müller, B.S., ed. Jacobsen-McGill Arctic Research Expedition to Axel Heiberg Island, Preliminary Report 1959-1960. Montreal: MeGill University. 179-199.

and WEIDICK, A. 1973. Geobotanical and geomorphological reconnaissance in West Greenland, 1961. Arctic and Alpine Research 5:311-319. 
BIRKENMAJER, K. 1980a. Age of the Penguin Island volcano, South Shetland Islands (West Antarctica) by the lichenometric method. Bulletin de l'Academie Polonaise des Sciences, Serie des Sciences de la Terre 27:69-76. 1980b. Lichenometric dating of glacier retreat at Admiralty Bay, King George Island (South Shetland Islands, West Antarctica). Bulletin de l'Academie Polonaise des Sciences, Serie des Sciences de la Terre 27:77-85.

CALKIN, P.E., and ELLIS, J.M. 1984. Development and application of a lichenometric dating curve, Brooks Range, Alaska. In: Mahaney, W.C., ed. Quaternary Dating Methods. Amsterdam: Elsevier. 227-246.

CARRARA, P.E., and ANDREWS, J.T. 1972. The Quatemary history of northern Cumberland Peninsula, Baffin Island, N.W.T. , Part I: The late- and Neoglacial deposits of the Akudlermuit and Boas Glaciers. Canadian Journal of Earth Sciences 9:403-414.

ELLIS, J.M., and CALKIN, P.E. 1984. Chronology of Holocene glaciation, central Brooks Range, Alaska. Geological Society of America Bulletin 95:897-912.

ELLIS, J.M., HAMILTON, T.D., and CALKIN, P.E. 1981. Holocene glaciation of the Arrigetch Peaks, Brooks Range, Alaska. Arctic 34:158-168.

FREEMAN, G.H. 1973. Statistical methods for the analysis of genotypeenvironment interactions. Heredity 31:339-354.

GORDON, J.E. 1981. Glacier margin fluctuations during the 19th and 20th centuries in the Ikamiut Kangerdluarssuat area, west Greenland. Arctic and Alpine Research 13:47-62.

GRIFFEY, N.J. 1977. A lichenometrical study of the Neoglacial end moraines of the Okstindan glaciers and comparisons with similar recent studies. Norsk geografisk Tidsskrift 31:163-172.

HILL, D.J. 1984. Studies on the growth of lichens I. Lobe formation and the maintenance of circularity in crustose species. The Lichenologist 16:273-278.
INNES, J.L. 1984. The optimal sample size in lichenometric studies. Arctic and Alpine Research 16:233-244.

1985. Lichenometry. Progress in Physical Geography 9:187-254.

1986. The use of percentage-cover measurements in lichenometric dating. Arctic and Alpine Research 18: in press.

LOCKE, C.W., and LOCKE, W.W., III. 1977. Little Ice Age snow-cover extent and paleo-glaciation thresholds: north central Baffin Island, N.W.T., Canada. Arctic and Alpine Research 9:291-300.

LOCKE, W.W., III, ANDREWS, J.T., and WEBBER, P.J. 1979. A manual for lichenometry. British Geomorphological Research Group Technical Bulletin 26. $45 \mathrm{p}$.

MATHER, K., and JINKS, J.L. 1977. Introduction to Biometrical Genetics. London: Chapman and Hall. $231 \mathrm{p}$.

MATTHEWS, J.A. 1974. Families of lichenometric dating curves from the Storbreen gletschervorfeld, Jotunheimen, Norway. Norsk geografisk Tidsskrift 28:215-235.

INNES, J.L., and CASELDINE, C.J. $1986 .{ }^{14} \mathrm{C}$ dating and palaeoenvironment of the historic 'Little Ice Age' glacier advance of Nigardsbreen, southwest Norway. Earth Surface Processes and Landforms 11: in press.

PITMAN, G.T.K. 1973. A lichenometrical study of snowpatch variation in the Frederikshab district, south-west Greenland and its implications for study of climatic and glacial fluctuations. Bulletin der Grønlands geologiske Undersolkse 104:1-31.

TEN BRINK, N.W., and CURL, J.E. 1973. Glaciology and glacial chronology in the South Shetland Islands. Antarctic Journal of the United States 8:175-177.

TUKEY, J.W. 1949. One degree of freedom for non-additivity. Biometrics 5:232-242. 